\title{
4 \\ Unintended Consequences of Temporary Migration to Australia
}

Peter Mares

\section{Introduction}

Some unintended consequences of temporary migration are wellknown. For example, under the Howard Government, linking certain courses of tertiary study in Australia with almost automatic permanent residency led to a dramatic increase in student enrolments in newly created private colleges offering the shortest route to permanent migration; this overwhelmed the permanent skilled migration program, with qualified applicants far outnumbering the places available in the system. ${ }^{1}$

Another familiar example is the way in which employer sponsorship for permanent residency risks making temporary migrant workers on 457 visas more vulnerable to workplace exploitation. This was examined in Barbara Deegan's 2008 review of the integrity of the 457 visa system. ${ }^{2}$

1 See, for example, Peter Mares, 'Lives On Hold', Inside Story, 2 May 2011. Available at: insidestory.org.au/lives-on-hold/.

2 Barbara Deegan, 'Visa Subclass 457 Integrity Review: Final Report' (2008). Available at: www.immi.gov.au/skilled/skilled-workers/_pdf/457-integrity-review.pdf. 
This chapter takes familiarity with these recognised unintended consequences of temporary migration as a given and aims to present some less well-known examples. The examples are chosen not just because they are interesting in their own right, but also because they serve to illustrate a broader point - namely, that the increased use of temporary migration as a tool of policy raises moral and practical issues that Australia as a society and a polity is yet to recognise or address.

In the previous chapter, Shanthi Robertson observed that "norms around migration are arguably still embedded within a "settler-citizen" paradigm, and understandings of temporary migrant experiences are particularly limited'. This chapter seeks to build on Robertson's insight in two ways. Firstly, it argues that just as the norms around migration remain embedded in an outdated paradigm, so too do administrative and legal structures, with the result that long term temporary migrants with work rights often find themselves falling into cracks in the system. These are the unintended consequences referred to in the title and illustrated in the examples below. Secondly, this chapter argues that an updated policy approach (and updated legal and administrative systems) must be based on updated norms, more appropriate to the new realities of Australia's migration program and the large role that temporary migration now plays in it. In this regard I draw on Joseph Carens' arguments about the moral impact of the passage of time on a receiving state's obligations towards temporary migrants, and use this to critique existing policy settings in Australia and to gesture at potential alternative approaches.

The fundamental argument is that, over time, questions around access to specific rights and entitlements for migrant workers - such as workplace protections or access to government services - ultimately resolve themselves into a question of political membership. In other words, they inevitably lead to the 'threshold' question: at what point does, or should, 'temporary' become 'permanent'?

This chapter cites examples of the unintended consequences of temporary migration as they play out in individual lives. These stories are based primarily on interviews and other materials gathered by the 
author in his capacity as a journalist. ${ }^{3}$ To put these stories in context, the chapter also assembles publicly available immigration department data to document the statistical significance of the rise in temporary migration to Australia in recent years.

\section{The false divide between temporary and permanent migration}

Policy-makers are want to present temporary migration as a neat and tidy affair that is quite distinct from permanent migration, as if they were two 'quite separate and unrelated processes'. ${ }^{4}$ This sentiment was evident in the words of Scott Morrison, the first Minister for Immigration in the Abbott Government, in a speech made when he was in Opposition:

We must be careful to manage the population impacts of ... temporary migration, ensuring that we apply appropriate constraints, most importantly that such entrants return home when their purpose and stay has been completed — whether it is to work, study or visit without onward application entitlements. ${ }^{5}$

Temporary migrants are expected to come to Australia, go about their business and then leave when their visa expires. Unfortunately for politicians, migration is an inherently messy process. As Dauvergne and Marsden note, while 'workers [or students] may be invited, it is human beings who arrive'. ${ }^{6}$ Over time, the boundaries between what constitutes a temporary stay and what constitutes longer-term engagement with the nation and the society tend to blur, especially

3 The author is currently contributing editor to the online news and culture magazine Inside Story, where many of his articles on temporary migration have appeared. Prior to 2012, he reported on these issues on The National Interest program on ABC Radio National.

4 Siew-Ean Khoo, Graeme Hugo and Peter McDonald, 'Which Skilled Temporary Migrants Become Permanent Residents and Why?' (2008) 42 International Migration Review 193.

5 Scott Morrison, 'Our Nation' (Address to the 2011 Federation of Ethnic Community Councils of Australia Conference, Adelaide, 18 November 2011). Available at: australianpolitics. com/2011/11/18/morrison-promises-to-protect-the-borders-of-our-values.html\#more-4574.

6 Catherine Dauvergne and Sarah Marsden, 'The Ideology of Temporary Labour Migration in the Post-Global Era' (2014) 18 Citizenship Studies 225. This reformulates the famous 1965 observation by Swiss playwright Max Frisch in relation to Italian guest workers: 'Man hat Arbeitskräfte gerufen, und es kamen Menschen.' (We called for labour power and human beings came.) 
when a temporary stay is constructed in policy terms - as is increasingly the case in Australia - as a potential first step towards permanency. $^{7}$

The biggest unintended consequence of temporary migration is, arguably, that the more time migrants spend living, working, and studying in Australia, the more financial, cultural, psychological, and emotional attachments they are likely to develop. (This process is appropriately described as putting down roots. After a short time the roots will be shallow. After a longer period, they will reach deeper.) As a result, these temporary migrants also accumulate rights moral rights, if not legal ones. Consequently, we as citizens, via the government that represents us, also accumulate obligations towards temporary migrants.

As documented in more detail below, the number of temporary migrants present in Australia has been growing steadily since the mid-1990s, with developments such as the introduction of the 457 temporary work visa, the expansion of the 'Working Holiday Maker' scheme, the internationalisation of Australia's education system, and changes to the status of New Zealanders living in Australia. What is more, it is now becoming apparent that increasing numbers of temporary migrants are renewing their visas or moving sequentially from one temporary visa subclass to another temporary visa subclass. This opens up the possibility for temporary migrants to be lawfully present in Australia and to be active and engaged members of Australian society for years at a time, without necessarily moving down a pathway to Australian residency or Australian citizenship, and the rights and entitlements that come with such status.

This poses new political and ethical questions for society. Carens has summarised the conundrum neatly by asking if there is a place for such long-term temporary migrants on the 'normative map' of liberal democracy. ${ }^{8}$ Neither short-term visitors nor permanent residents, these migrants work and study, pay taxes and university fees, abide

7 For a discussion on how the 457 temporary skilled worker visa is now a fundamental component of the process for selecting permanent migrants, see, for example, Peter Mares, 'Temporary Migration is a Permanent Thing', Inside Story, 20 March 2013. Available at: inside. org.au/temporary-migration-is-a-permanent-thing/.

8 Joseph H Carens, 'Live-in Domestics, Seasonal Workers, and Others Hard to Locate on the Map of Democracy' (2008) 16 The Journal of Political Philosophy 419, 420. 
by laws and contribute to the economic and cultural life of the nation in myriad other ways. Carens asks whether liberal democracies should be able to admit people to their societies in this way, 'without putting them on a path to citizenship and without granting them most of the rights that citizens enjoy'? ${ }^{9}$ His answer (framed as a question of justice, rather than political pragmatism) inclines towards a 'no'. When combined with 'the moral importance of the passage of time', he argues that both 'the inner logic of democracy and a commitment to liberal principles require the full inclusion of the entire settled population', because 'the longer the stay, the stronger the claim to full membership in society and to the enjoyment of the same rights as citizens, including, eventually, citizenship itself ${ }^{\prime}{ }^{10}$

As Shanthi Robertson has observed in relation to international students, the rise of temporary migration is 'radically different to the trend of permanent settler migration' that characterised Australian policy in the second half of the twentieth century. ${ }^{11}$ As a result, "paradigms of settlement, permanent residency and full citizenship ... are being destabilised'. ${ }^{12}$ Yet to date, the important questions raised by Carens have not engaged the attention of many Australian policymakers or theorists. ${ }^{13}$

In fact, we even lack the appropriate language to discuss these issues. The term 'guest worker' (or Gastarbeiter) with its specific historical connotations and references is clearly inadequate to encompass a range of temporary migrants that includes both high-skilled professionals and undergraduate students. Like the term 'sojourner', ${ }^{14}$ it also implies a degree of temporariness that assumes return and does not accord with the emerging reality of " "staggered" migration processes, characterised by multiple "gates" of membership that migrants must pass through to enter the nation state' ${ }^{15}$ An alternative

\footnotetext{
9 Ibid., 419.

10 Ibid.

11 Shanthi Robertson, Transnational Student-Migrants and the State: The Education-Migration Nexus (Palgrave Macmillan, 2013) 1.

12 Ibid., 166.

13 There are exceptions, including notably, Shanthi Robertson, above fn 11; Joo-Cheong Tham, 'Multiculturalism and Temporary Migration: Where Does Justice Fit?' (Presentation to Australian Multicultural Commission roundtable, Melbourne, 15 March 2013).

14 Shanthi Robertson, above fn 11, 41.

15 Ibid., 68.
} 
that is sometimes offered is 'denizens', while Michael Walzer compares such long-term temporary residents to the metics of ancient Athens, foreigners in the city who were neither citizens nor slaves. ${ }^{16}$

For reasons of clarity, this chapter refers to 'long-term temporary migrants with work rights', thus encompassing international students and working holiday makers, as well as migrant workers on 457 visas. It is a rather clumsy formulation and even here the language is potentially inadequate since reference is also made to New Zealanders, whose Special Category Visas (SCVs) render their presence in Australia as neither temporary nor permanent, but rather indefinite. ${ }^{17}$ (As outlined below, however, the SCV is classified as a temporary visa in migration law.)

\section{Example 1: Temporary migrants and workers' compensation}

When 34-year-old English nurse Claire Hewitt migrated to the Northern Territory (NT) in 2009, it was no rash or random decision. Together with her photographer husband, Terry, she had spent the previous year travelling around Australia in a campervan and had fallen in love with the outback. After having a good look around, the couple decided where they wanted to go and what they wanted to do. ${ }^{18}$

As a registered nurse, Hewitt could have found a job in Sydney or Melbourne, but she reckons that would have been little different to working in a clinic in London. She says she wanted to do something that she could not do anywhere else.

The couple settled in Alice Springs so Hewitt could take up a job with the NT Government working on a trachoma treatment and prevention program in remote Aboriginal communities.

\footnotetext{
16 Michael Walzer, Spheres of Justice: A Defense of Pluralism and Equality (Basic Books, 1983) 53.

17 For discussion of whether the SCV is a temporary or permanent visa, see David Faulkner,

'The Unequal Treatment of New Zealanders in Australia' (2013). Available at: papers.ssrn.com/ sol3/papers.cfm?abstract_id=2304476.

18 Interview with Claire Hewitt (29 August 2013). The following outline of Claire Hewitt's story is based on the above interview, which was conducted as research for the following article: Peter Mares, 'Falling Between the Cracks of Temporary Migration', Inside Story, 1 November 2013. Available at: inside.org.au/falling-between-the-cracks-of-temporary-migration/. (The article was provided to Ms Hewitt for fact checking prior to publication and published with her permission.)
} 
This is important work. Trachoma is an easily treatable and easily preventable eye disease and is the leading cause of infectious blindness in 59 of the world's poorest countries. Australia is the only developed country in the world to still have active trachoma in remote Indigenous communities. ${ }^{19}$

If it had been possible, the couple would have migrated to Australia on a permanent visa, perhaps under the Employer Nomination or Regional Sponsored Migration Scheme. However, NT authorities told Hewitt that they had had bad experiences with permanent skilled migration: new arrivals would often be unprepared for local conditions and quickly decamp to a larger city in another part of Australia with a less extreme climate. She says the NT health department encouraged her to come on a 457 visa instead. ${ }^{20}$ She was given to understand that if she liked the work and the lifestyle, then, after 12 months, the department would sponsor her for permanent residency.

Hewitt and her husband were in the middle of doing the paperwork for that application when she had her accident.

On 18 May 2010, while driving to the remote community of Mt Leibig, Hewitt rolled her car six times. She was lucky to survive after being trapped in the vehicle for a long time and receiving massive head injuries, 33 fractures to her chest, and severe nerve damage to both arms.

Hewitt was hospitalised for three months and underwent major surgery, including a procedure to transfer her pectoral muscle from her chest to her shoulder to restore her ability to raise her left arm. It was an operation performed only once before in Australia. Eighteenmonths of full-time rehabilitation followed and, three years later, much of Hewitt's routine still revolves around appointments with therapists and specialists. Since the accident, her husband Terry has been devoted almost full-time to her care.

19 Melbourne School of Population and Global Health, Indigenous Eye Health Unit, The Trachoma Story Kit. Available at: iehu.unimelb.edu.au/the_trachoma_story_kit/introduction.

20 This approach was presumably based on the assumption that labour mobility amongst temporary 457 visa holders is lower than amongst permanent residents (due to the fact that a temporary migrant's visa status is linked to ongoing employment with an eligible sponsor). 
It is a nightmare story, but Hewitt's recovery has astounded her doctors. The rehabilitation specialist consulting on her case, Associate Professor Les Koopowitz from the University of Adelaide, commented that Hewitt 'continues to attain the type of progress seldom realised following such a serious, devastating and debilitating accident ${ }^{\prime} .{ }^{21}$

As a result of the crash, Hewitt expects to have a lifetime of disability, pain, and medical conditions. She accepts that she cannot return to her old job in remote communities, but is nevertheless determined to return to nursing in some capacity. 'Right from the beginning they almost had to hold me down to stop me trying to go back to work', she said. 'In a way I haven't helped myself. I tried to do too much too soon. My brain has to relearn things and that takes time. ${ }^{22}$

Hewitt says that throughout her long rehabilitation, the NT Department of Health assured her that it would fully support her eventual return to work, including tailoring her duties to her abilities where necessary.

In mid-2013, however, everything changed when the department indicated that it would no longer sponsor her application for a permanent visa. This made it likely that she would have to leave Australia when her temporary 457 visa expired in June 2014.

The implications for Hewitt were profound. If Hewitt had to leave Australia, then she would lose access to the extensive medical and rehabilitation team that have worked with her for the past three years. As a result, she would probably also lose any realistic chance of returning to her career as a nurse.

Professor Koopowitz argues that Hewitt's ongoing recovery is highly dependent on 'continuity of care and environmental stability', and that undermining this could seriously compromise her ongoing recovery and render hopes of a return to any meaningful work 'an unrealistic challenge'.

At the time of her crash, Hewitt was at work and driving a government vehicle. In other words, it was a workplace accident, and Hewitt was covered by workers' compensation. NT Workcover pays her medical bills, and she continues to receive 75 per cent of her salary.

21 Email from Les Koopowitz to the author (23 October 2013).

22 Interview with Claire Hewitt, above fn 18. 
The NT Workers Rehabilitation and Compensation Act states that:

rehabilitation means the process necessary to ensure, as far as is practicable, having regard to community standards from time to time, that an injured worker is restored to the same physical, economic and social condition in which the worker was before suffering the relevant injury. $^{23}$

The Act makes no reference to a worker's visa status. There has never before been a case like Hewitt's under the NT scheme.

Hewitt's legal advice is that if she has to leave Australia and return to the UK, then medical bills relating to her accident will still be paid by the compensation scheme. Her salary entitlements, however, are a different matter.

If Hewitt were a permanent resident and unable to return to work full-time, or at the same pay level as at the time of her accident, then the workers' compensation scheme would top up her salary so that her original income was maintained. In the event that Hewitt was unable to return to work at all, she would receive 75 per cent of her original salary. Either way, the entitlement would continue until the age of 67 .

If, however, Hewitt leaves Australia, then her salary entitlements would cut out after two, or possibly, four years. After that time Hewitt would have to rely on UK government disability benefits.

Hewitt says the NT health department told her in 2013 that she no longer met the criteria for sponsorship as a skilled migrant. This may or may not have been true, but she wanted the department to sponsor her application even if it was doomed to failure, because she believed and was advised that her best hope of staying in Australia ultimately lay with ministerial intervention. ${ }^{24}$ But there is a Catch 22 here: the immigration minister cannot use his discretion to intervene in a migration case (even when there are compelling and compassionate circumstances) until all other avenues of appeal have been exhausted. The minister's public interest power to substitute a decision that is more favourable to the applicant in migration cases requires 'a review tribunal decision to exist

23 Workers Rehabilitation and Compensation Act (NT) pt V div 4 (2). (Emphasis in original.)

24 Under the Migration Act 1958 (Cth) s351(1), s417(1) and s501J(1), the minister may, in the public interest, substitute for a decision of a tribunal, a decision that is more favourable to the applicant. 
before he can intervene' ${ }^{25}$ In the context of immigration decisions, a 'review tribunal' means 'the Refugee Review Tribunal (RRT), the Migration Review Tribunal (MRT) or, in certain circumstances, the Administrative Appeals Tribunal (AAT) ${ }^{\prime}{ }^{26}$ Unless the NT lodged an application that fails, Hewitt would have no decision to appeal to a tribunal and could not therefore seek ministerial intervention.

'Our lives are here', said Hewitt. 'We didn't come here with the intention of having a holiday, we moved ourselves lock, stock and barrel. ${ }^{\prime 27}$ And after all that Hewitt has been through, Australia is more home than ever.

After members of parliament and journalists drew public attention to Hewitt's case, the NT health department wrote to her advising that it would, after all, sponsor her application for a permanent visa. A visa was eventually granted in October $2014 .{ }^{28}$

Even though the eventual outcome for Hewitt was positive, the ad hoc arrangements reached in her particular case do not resolve the outstanding tensions and contradictions that gave rise to it in the first place.

Hewitt's predicament is one disturbing example of an unintended consequence of the rise of temporary migration in Australia. While her case is highly specific and personal, it is predictable, indeed likely, that similar cases will arise in future, since many of Australia's legal and institutional structures are based on the assumption that if people are not citizens or permanent residents of Australia, then they are here only as short-term visitors. Administrative and legal systems have not been designed to envisage a situation in which a significant and growing proportion of the population consists of people like Hewitt - long-term temporary migrants with work rights.

Such people cannot be simply and neatly defined. They are resident in Australia, but they are not, legally speaking, residents. It is the visas they hold that define their status, and since there are a range of different long-term temporary visas that come with permission

25 Department of Immigration and Border Protection, Ministerial Intervention (14 May 2014). Available at: www.immi.gov.au/refugee/ministerial_intervention.htm (site discontinued).

26 Ibid.

27 Interview with Claire Hewitt, above fn 18.

28 Email from Claire and Terry Hewitt to the author (10 February 2015). 
to work, different cohorts within this group enjoy (or lack) different rights and entitlements. What can be said in general about this group is that they are all non-Australians, and that as their numbers grow, more of them will find themselves falling between legislative and regulatory cracks that were not previously apparent.

\section{Example 2: Temporary migrants and the Fair Entitlements Guarantee}

When Tony Abbott was Employment Minister in the Howard Government, he set up GEERS - the General Employee Entitlements and Redundancy Scheme. Its creation followed the collapse of a string of high-profile companies - One-Tel, HIH, Ansett, and National Textiles (a company run by John Howard's brother, Stan, that went bust leaving 342 workers with unpaid entitlements). GEERS is now known as FEG - the Fair Entitlements Guarantee - but its function remains essentially the same. It is a scheme to cover the unpaid wages and holiday entitlements of workers whose employer goes bankrupt.

In May 2013, the Swan Services Cleaning Group went into administration owing \$2.3 million in unpaid wages and \$7.2 million in annual leave entitlements to around 2,500 workers. ${ }^{29}$ But many if not most of those workers will not qualify for payments under the FEG, because to be eligible under the Act a person must be 'an Australian citizen or, under the Migration Act 1958, the holder of a permanent visa or a special category visa'. ${ }^{30}$

A large proportion of the Swan Services workforce - about half of its staff in Victoria - was made up of international students. Many were left with up to three weeks' worth of unpaid wages, and some were owed close to $\$ 3,000 .{ }^{31}$ Like Claire Hewitt, they have fallen into a regulatory crack where the government assistance extended to their fellow workers does not reach.

29 United Voice, Swan Cleaning Services Update (5 June 2013). Available at: www.unitedvoice. org.au/news/swan-cleaning-services-update.

30 Fair Entitlements Guarantee Act 2012 (Cth) pt 2 div 1 sub-div A para 10 (1) (g). SCV holders are New Zealanders.

31 Madeleine Heffernan and Clay Lucas, 'International Students Taken to the Cleaners', The Age, 2 June 2013. Available at: www.theage.com.au/national/international-studentstaken-to-the-cleaners-20130601-2nily.html\#ixzz2iQHeVVzWwww.theage.com.au/national/ international-students-taken-to-the-cleaners-20130601-2nily.html\#ixzz2iQHeVVzW. 


\section{Example 3: New Zealanders}

Many New Zealanders found themselves caught in a different regulatory gap during the devastating floods that hit Queensland in the summer of 2009-10. To help people get through the worst of the crisis, the Commonwealth Government authorised emergency funds for affected households of $\$ 1,000$ per adult and $\$ 400$ per child under the Australian Government Disaster Recovery Payment scheme. To be eligible for such payments, however, a person must meet the definition of 'Australian resident' under social security laws. Many long-term New Zealander residents were denied the emergency assistance because they had settled in Australia after 26 February 2001, when the Family and Community Services Legislation Amendment (New Zealand citizens) Act 2001 came into force. The Act changed 'the definition of Australian resident for the purposes of the social security law', with the specific intention of 'restricting access to social security payments' for New Zealanders. ${ }^{32}$

The flood payments issue caused considerable controversy and media comment, as New Zealanders who had bought houses, and had children and established businesses in Australia were denied the same assistance as was offered to their neighbours. Many felt that they were being treated as 'second class citizens'. ${ }^{33}$ A more accurate - though less catchy - complaint would have been that they were being treated as second-class permanent residents, since they had the right to reside and work indefinitely in Australia but did not have access to the same entitlements as other permanent residents.

Perceptions of Australian meanness at a time of need were amplified a few weeks later by the New Zealand Government's response to the 2011 Christchurch earthquake: Australians resident in that city were offered the same emergency and unemployment benefits as New Zealand citizens. ${ }^{34}$

32 Explanatory Memorandum, Family And Community Services Legislation Amendment (New Zealand Citizens) Bill 2001. (Emphasis in original.) On arrival in Australia, New Zealanders are automatically issued with a SCV that entitles them to work and live indefinitely in the country. New Zealanders resident in Australia prior to 2001 were exempt from the changes and are described as 'protected SCV holders'.

33 Hayden Donnell, 'New Zealand Pair Upset at Flood Cash "Racism"”, New Zealand Herald, 21 January 2011. Available at: www.nzherald.co.nz/nz/news/article.cfm?c_id=1\& objectid $=10701102$.

34 David Faulkner, above fn 17. 
The outcry on both sides of the Tasman about the flood payments issue and official lobbying from Wellington eventually pressured the federal government into providing 'ex-gratia assistance payments' to New Zealanders who could demonstrate that they had been working in Australia for the three previous years. ${ }^{35}$ This appears to have set a precedent that is now routinely repeated in response to other disasters. Similar ex-gratia payments have subsequently been made available to otherwise ineligible New Zealanders who were affected by the 2013 floods in Queensland ${ }^{36}$ and NSW, ${ }^{37}$ and by bushfires in October 2013 in $\mathrm{NSW}^{38}$ and in January 2014 in WA. ${ }^{39}$

In response to recent disasters, the Commonwealth is also offering to pay an ex-gratia Income Support Allowance to New Zealanders who arrived in Australia after 26 February 2001 (and who are, therefore, ineligible for other forms of welfare such as unemployment benefits). ${ }^{40}$

Thus the situation as it stands is that eligibility for Australian Government Disaster Recovery Payments and emergency income support are restricted to those who qualify as residents for social security purposes, and exclude New Zealanders who arrived after 26 February 2001 and are therefore holders of non-protected SCVs. This is in line with the scope and intent of the 2001 amendments. Yet because the implications of this arrangement are politically and

35 New Zealand High Commission Canberra, Australia, Floods Assistance. Available at: www.nzembassy.com/australia/news/queensland-floods-assistance (site discontinued).

36 Department of Human Services, Australian Government, Ex-Gratia Assistance for New Zealand Non-Protected Special Category Visa Holders: Queensland Floods January 2013. Available at: www. humanservices.gov.au/spw/customer/forms/resources/em037-130212en.pdf (site discontinued).

37 Department of Human Services, Australian Government, Ex-Gratia Assistance For New Zealand Non-Protected Special Category Visa Holders: New South Wales Floods January 2013. Available at: www.humanservices.gov.au/spw/customer/forms/resources/em039-130215en.pdf (site discontinued).

38 Department of Human Services, Australian Government, New South Wales Bushfires: October 2013. Available at: www.humanservices.gov.au/customer/services/centrelink/dra-nswbushfires-october-2013 (site discontinued).

39 Department of Human Services, Australian Government, Western Australia Bushfires: January 2014. Available at: www.humanservices.gov.au/customer/enablers/centrelink/ australian-government-disaster-recovery-payment/western-australia-bushfires-january-2014 (site discontinued).

40 See for example Department of Human Services, Australian Government, Ex-Gratia Income Support Allowance for New Zealand Non-Protected Special Category Visa Holders: NSW Bushfires October 2013. Available at: www.humanservices.gov.au/customer/enablers/ centrelink/disaster-recovery-allowance/ex-gratia-income-support-allowance-nsw-bushfiresoct-2013\#a4 (site discontinued). 
diplomatically unpalatable, the federal government feels compelled to repeatedly patch the system by applying the band-aid of ex-gratia payments.

Another anomaly affecting New Zealanders who have settled in Australia after 2001 is that they will be required to contribute to the National Disability Insurance Scheme - now called Disability Care Australia - but will not be entitled to access any of the support it provides. This is because the residency requirements for eligibility under the National Disability Insurance Scheme Act 2013 (Cth) exclude New Zealanders who are not protected SCV holders. ${ }^{41}$ However, the definition of 'Australian resident' in the Health Insurance Act 1973 makes all SCV holders (protected and unprotected alike) liable to pay the Medicare levy and the additional impost to finance the disability scheme. ${ }^{42}$ As a result, 'many New Zealand citizens will be directly taxed for a disability scheme they cannot access' ${ }^{43}$ It is hard not to sympathise with the view that this amounts to unfair and discriminatory treatment.

In many states it is already the case that New Zealanders are ineligible for support services if they live with a disability. When cerebral palsy sufferer Hannah Campbell challenged her treatment in court, the Queensland Government agreed to pay an undisclosed sum to cover the costs of her care. However, because the matter was settled out of court, the case failed to set a precedent for other New Zealanders. As her lawyer commented at the time, the Queensland Government dodged a 'multimillion-dollar bullet'. ${ }^{44}$ The introduction of Disability Care Australia will eliminate the differences between states and remove any doubt - New Zealanders will be excluded from support services. ${ }^{45}$

\footnotetext{
$41 \quad$ National Disability Insurance Scheme Act 2013 (Cth) ch 3 pt 123.

42 Health Insurance Act 1973 (Cth) pt 1 s 3(1)c.

43 David Faulkner, above fn 17.

44 Ben Heather, Kiwis' Australian Care Case Settled', Stuff NZ, 25 October 2012. Available at: www.stuff.co.nz/world/australia/7858803/Kiwis-Australian-care-case-settled.

45 The set of government entitlements available or denied to non-protected SCV holders is complicated and varies between different states and territories. For example, New Zealand tertiary students receive concessional public transport fares in New South Wales but not in Victoria. For further discussion of this issue see Peter Mares, 'A Special Category' (2014) 43 Griffith Review. Available at: griffithreview.com/articles/9677/; David Faulkner, above fn 17.
} 
It might be objected that New Zealanders who have been living and working in Australia on non-protected SCVs could obviate all these problems by becoming Australian residents. Often, however, this is not a straightforward matter. In accord with the 1973 bilateral TransTasman Travel Arrangement, all New Zealanders are granted an SCV on arrival in Australia (unless there are health or character concerns). ${ }^{46}$ There are no qualification requirements for New Zealanders to enter the Australian workforce, and although the Migration Act 1958 (Cth) describes the visa as a 'temporary visa', ${ }^{47}$ there are no limits on the duration of stay. However, a New Zealander who aspires to become a permanent resident of Australia must meet the same occupational, health, and age requirements as any other applicant in the skilled or family streams of the migration program. If New Zealanders are not the immediate family member of an Australian citizen, or if they do not have a profession that is in short supply - such as a profession on the Consolidated Sponsored Occupation List ${ }^{48}$ — or if they are over 50 years of age, then it is unlikely that they will ever qualify for permanent residency. The amount of time they have spent living and working in Australia is of marginal benefit to their migration application but never sufficient to secure permanent residency without satisfying other criteria.

\section{Example 4: Childhood immunisation}

Another example of the way in which regulatory systems fail to adequately account for the increase in long-term temporary migration to Australia is childhood immunisation. In the interests of public health, the Australian Government provides free childhood vaccinations for a wide range of communicable diseases, however, this service is restricted to citizens, permanent residents, and other people eligible to hold a Medicare card (so in this case all New Zealanders do qualify). ${ }^{49}$

\footnotetext{
46 Migration Act 1958 (Cth) pt 2 div 3 sub-div A s32.

47 Ibid.

48 An occupation on this list is required for permanent migration under the skills stream via employer or a state or territory government nomination.

49 See, for example, Department of Health, Victorian Government, Free Vaccine Victoria Criteria For Eligibility. Available at: www.health.vic.gov.au/immunisation/free-vaccine.htm (site discontinued). The Commonwealth Department of Health confirms that the same eligibility criteria apply nationwide (email correspondence with the author, 13 October 2013).
} 
According to a community nurse and midwife working in Victoria, public health staff in her local government area have been instructed to tell 457 visa holders, international students, and other temporary visa holders who are not eligible for free immunisations that they should take their baby or child to a general practitioner for vaccination. ${ }^{50}$ While international students and 457 visa holders are required to take out private health insurance that may rebate the cost of vaccinations (at least up to the level of the standard Medicare rebate), she is concerned that this restriction may result in immunisations being postponed or not carried out at all. Migrants and culturally and linguistically diverse communities are regarded as one of the 'special-risk and under-served populations' for immunisation. ${ }^{51}$ As a result, tracking the percentage of children who are fully immunised is more difficult in areas with large immigrant populations. ${ }^{52}$ While immunisation providers are expected to have a comprehensive understanding of the eligibility rules for access to free or subsidised vaccines, 'differences in eligibility by vaccine and visa class add complexity and act as a barrier to the provision of catch-up immunisation' in communities that are 'particularly vulnerable to under-immunisation'.$^{53}$ Excluding a proportion of that migration population from mass immunisation schemes on the basis of their visa status serves to further complicate an already complex situation. Given official concern at gaps in comprehensive childhood immunisation in Australia, ${ }^{54}$ this policy appears decidedly short-sighted.

50 Personal interview with the author (15 November 2013). Name withheld at interviewee's request for privacy reasons.

51 National Centre for Immunisation Research and Surveillance, 'Biennial Report: January 2010 - November 2011' (2012). Available at: www.ncirs.edu.au/assets/publications/reports/ NCIRS-biennial-report-2010-2011.pdf.

52 The National Health Performance Authority, Healthy Communities: Immunization Rates for Children in 2012-13. Available at: www.myhealthycommunities.gov.au/Content/publications/ downloads/NHPA_HC_Report_Imm_Rates_March_2014.pdf.

53 NHMRC Centre for Research Excellence in Population Health, Protecting Australia: Closing the Gap in Immunisation for Migrants and Refugees: Proceedings from a Stakeholder Workshop. Available at: creimmunisation.com.au/sites/default/files/newsevents/events/Proceedings_CRE MigrantRefugeeWorkshop.pdf.

54 See, for example, The National Health Performance Authority, 'Childhood Immunisation Rates Up, But Some Areas Still Low', (Media Release, 24 March 2014). 


\section{The rise and rise of temporary migration}

Temporary migration is no longer some marginal or temporary phenomenon at the edges of our migration program, but is now central to it. Increasingly, Australia has a 'two step' or 'try before you buy' migration program, which means a growing share of people taking up places in Australia's permanent migration program are already living here and have often been living here for several years.

The increase in temporary migration to Australia since 1999 is illustrated in Figure 4.1. For reasons outlined below, the number of 485 (skilled graduate) visa holders - the smallest category shown can be expected to increase sharply in coming years.

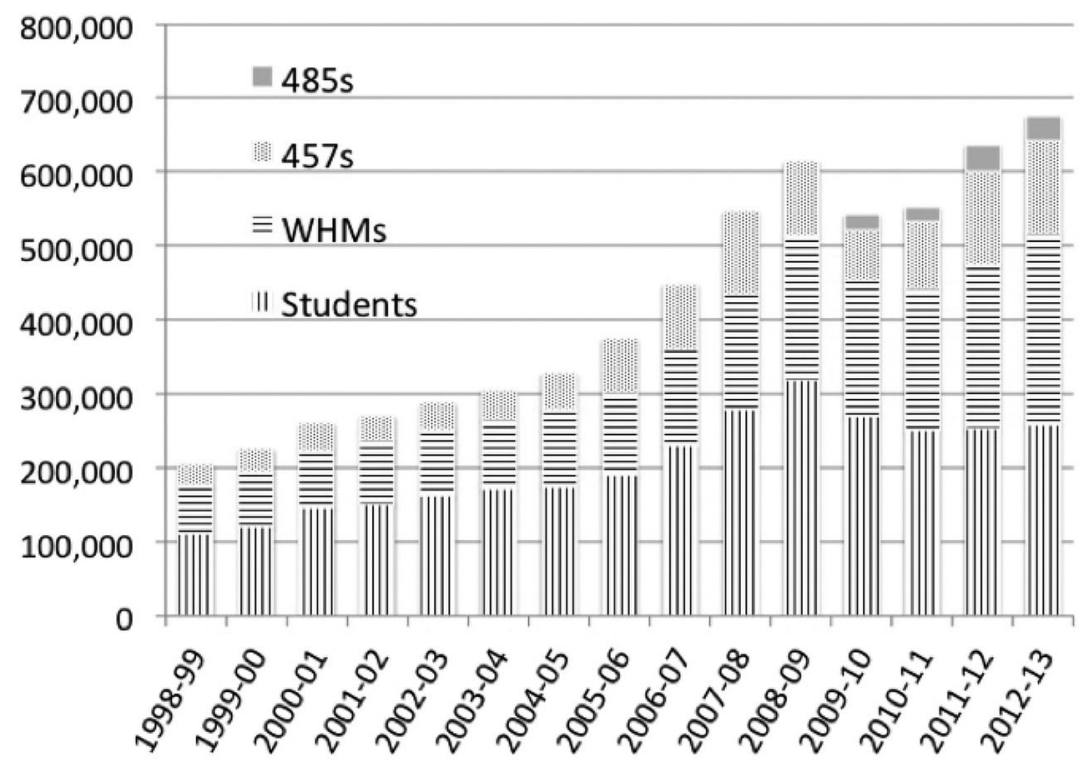

Figure 4.1: Growth in temporary visas issued 1999-2013.

Note: Includes both primary and secondary visa holders. WHM includes both 'Working Holiday Maker' visas and 'Work and Holiday Maker' visas.

Source: Department of Immigration and Citizenship. ${ }^{55}$

55 The department has since been renamed the Department of Immigration and Border Protection, and has been known by other names in previous years (such as the Department of Immigration and Multicultural Affairs). Specific source documents are 'Annual Report' (19992013); 'Student Visa Program' (2006-07 to 2012-13); 'Subclass 457 State/Territory Summary Report' (2007-13), 'Working Holiday Maker Visa Program Report' (30 June 2013); 'Working Holiday and Work and Holiday Visa Report', 2005-06 to 2009-10 Program Years. 
The substantial contribution of New Zealanders to Net Overseas Migration (NOM) to Australia is shown in Figure 4.2. As a result of the 2001 changes to the definition of 'Australian resident' outlined above, a growing proportion of Australia's New Zealand-born population are denied substantial entitlements that accrue to permanent residents.

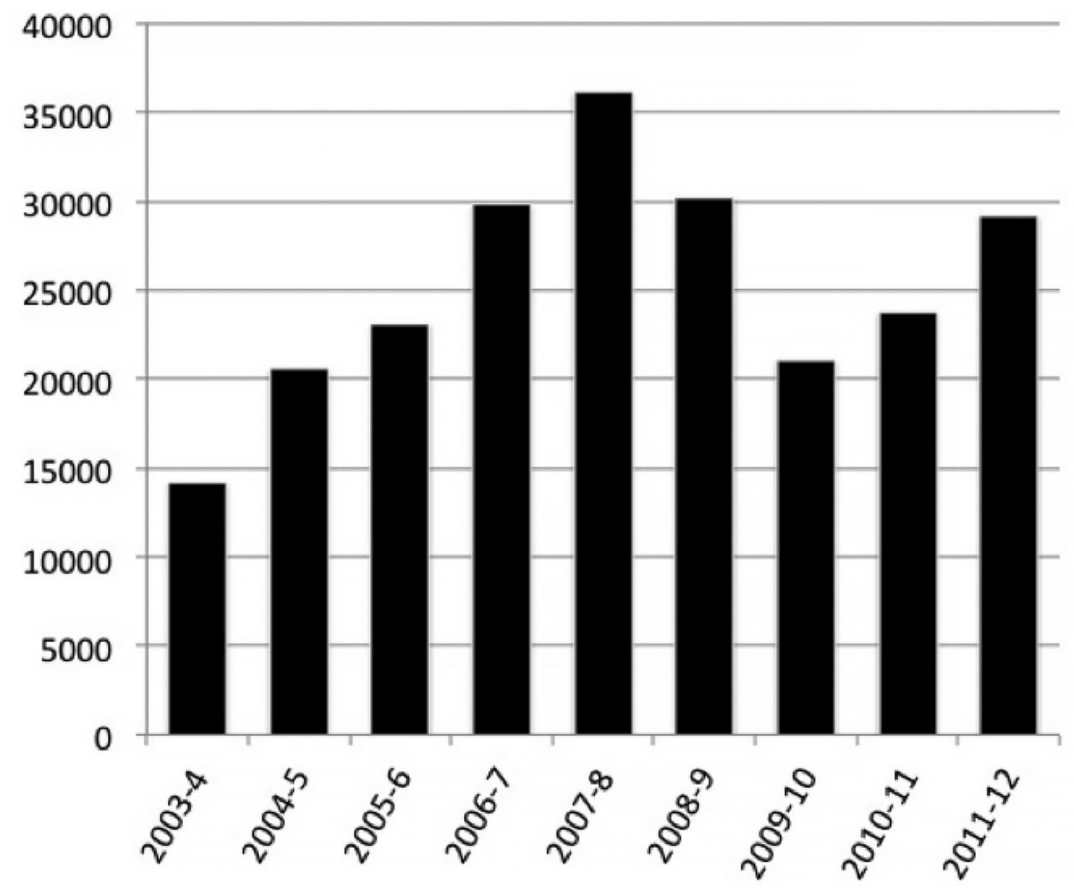

Figure 4.2: New Zealand contribution to Net Overseas Migration 2004-12. Source: Department of Immigration and Citizenship..$^{56}$

The number of temporary skilled migrants entering Australia each year under the 457 visa program now rivals (and sometimes exceeds) the size of the annual permanent skilled migration intake, as shown in Figure 4.3.

56 Department of Immigration and Citizenship, 'Australian Migration Trends 2011-12' (2012) 98. 


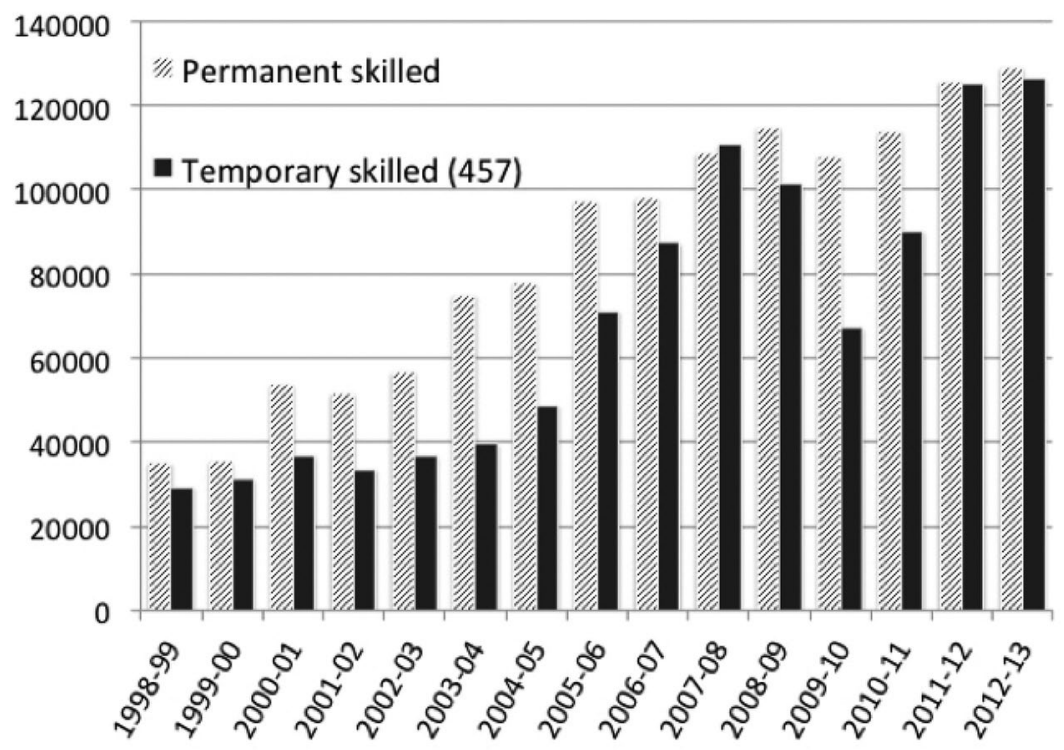

Figure 4.3: Temporary v permanent skilled visas 1999-2013.

Source: Department of Immigration and Citizenship. ${ }^{57}$

Another indication of the growing importance of temporary migration to Australia can be seen in the number of temporary migrants present in Australia at any given time. In the seven years from 2006 to 2013, the number more than doubled, from around 350,000 temporary migrants to close to 800,000 . It should be noted, too, that in addition to the four categories of visa holders depicted in Figure 4.4 (457 visa holders, 485 visa holders, bridging visa holders, and working holiday makers), by 2013 there were an estimated 200,000 New Zealanders living in Australia on non-protected SCVs. ${ }^{58}$ As outlined above, despite their right to reside and work in Australia indefinitely, in many respects this cohort of New Zealanders are in a similar situation to temporary migrants.

57 Department of Immigration and Citizenship, 'Annual Report' (1999-2013); 'Subclass 457 State/Territory Summary Report' (2007-13).

58 Kate McMillan and Paul Harmer, 'Kiwis in Australia Deserve Better', New Zealand Herald, 10 October 2013. Available at: www.nzherald.co.nz/nz/news/article.cfm?c_id=1\& objectid $=11137557$. 


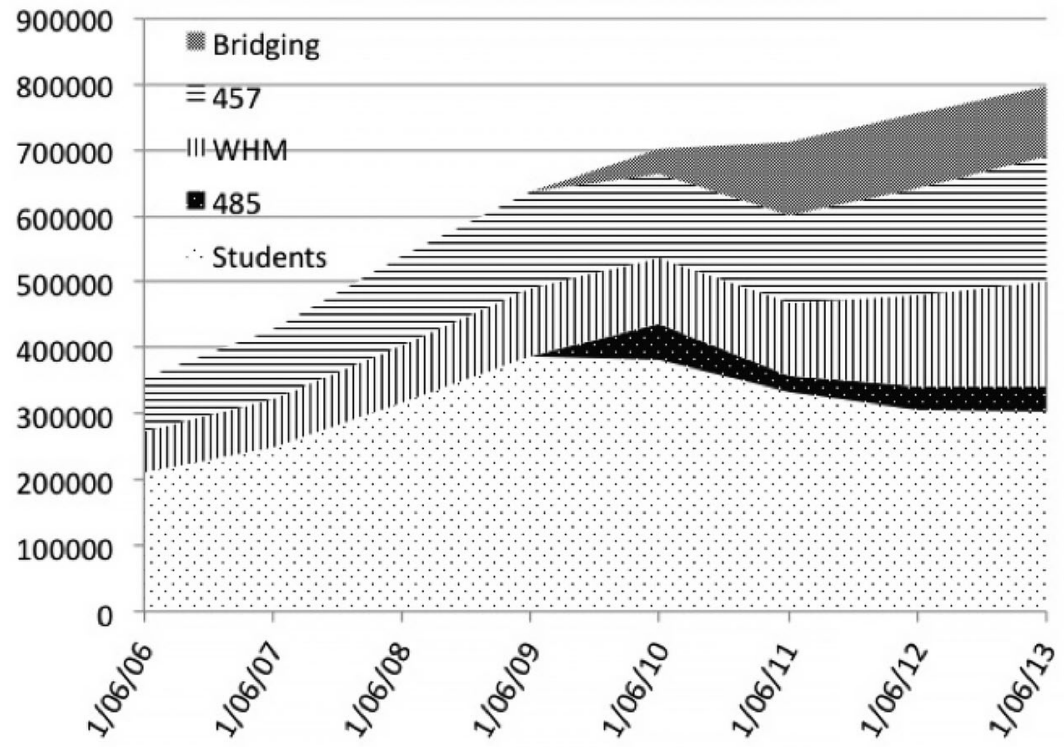

Figure 4.4: Temporary residents with work rights 2006-13 (stock).

Source: Department of Immigration and Citizenship. ${ }^{59}$

As shown in Figure 4.5, temporary migrants with work rights make up a significant and growing proportion of the Australian labour force, with the share rising from 3.3 per cent in 2006 to 6.4 per cent in 2013. (This calculation excludes New Zealanders on non-protected SCVs. Their inclusion would take the share closer to 9 per cent.)

59 Immigration Updates 2006-10, Temporary Entrants and NZ Citizens in Australia Quarterly Reports 2011-13. It might be argued that bridging visa holders should not be included in this calculation, however, most bridging visa holders do have work rights. The growth in the number of bridging visa holders is in itself evidence of the growing gap between the demand and supply of permanent residency spots, since many bridging visa holders are stuck in the processing 'queue' for residency. 


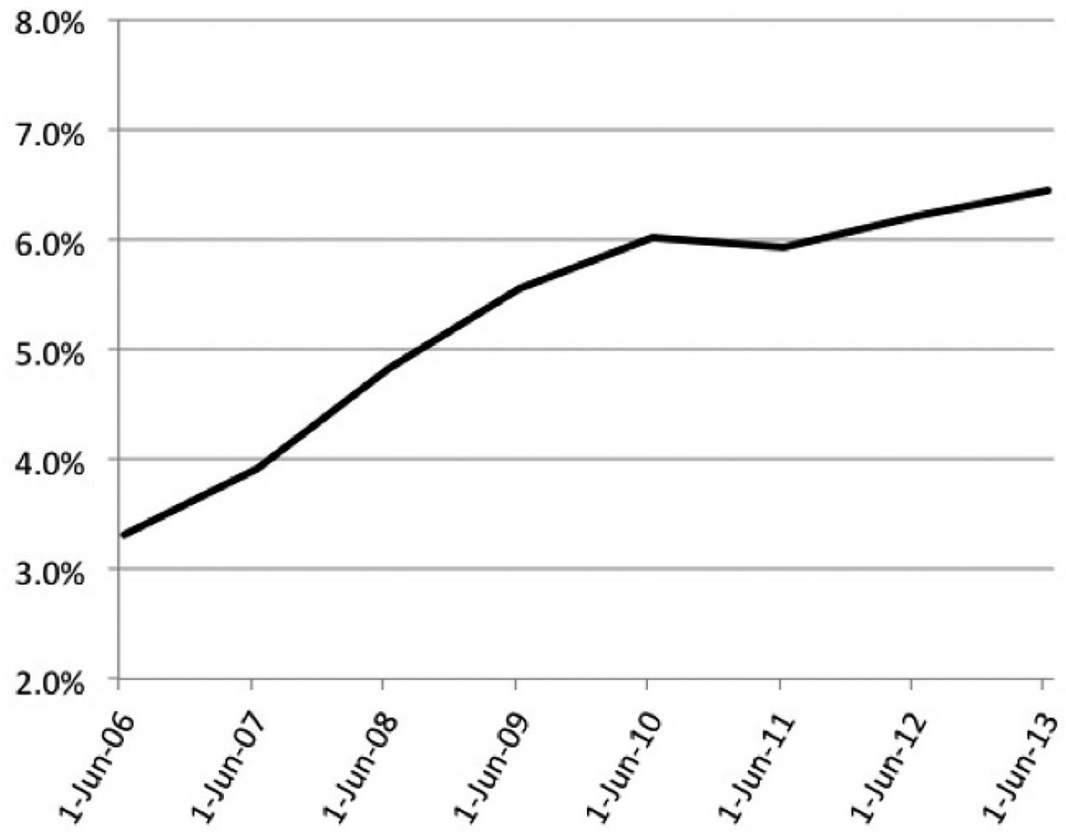

Figure 4.5: Temporary residents as percentage of the labour force.

Source: Department of Immigration and Citizenship and Australian Bureau of Statistics. ${ }^{60}$

\section{Implications}

In considering the rapid growth in temporary migration to Australia in recent years, two facts are particularly important.

Firstly, the permanent migration program has an annual cap, while the number of temporary migrants admitted to the country is openended. Secondly, a significant proportion of temporary migrants hope to settle permanently in Australia. The most comprehensive available survey of 457 (temporary skilled worker) visa holders, for example, suggests that around 70 per cent intend to apply for permanent residency when their temporary visa expires, ${ }^{61}$ while a 2007 survey of international students found 65 per cent intended to seek permanent

60 Ibid., and Australian Bureau of Statistics, Series 6202 Labour Force, Australia. Available at: www.abs.gov.au/ausstats/abs\%40.nsf/mf/6202.0. If the estimated 200,000 New Zealanders on non-protected SCVs was included, the proportion would be more than 8 per cent.

61 Scott Morrison, above fn 5. 
residency. ${ }^{62}$ (One survey of second-year accounting students at a Melbourne University found that 84 per cent intended to seek permanent residency. $)^{63}$

Given these two facts, it appears likely that, over time, Australia will experience an increasing mismatch between the aspirations of temporary migrants to become permanent residents and the capacity of growing numbers of them to realise that goal.

Already the data shows a growing gap between the number of 457 visas issued each year and the number of 457 visa holders who convert to permanent residency. As can be seen in Figure 4.6, the number of 457 visas converting annually to permanent residency has stagnated since 2008-09, despite a large increase in the number of temporary visas issued in subsequent years.

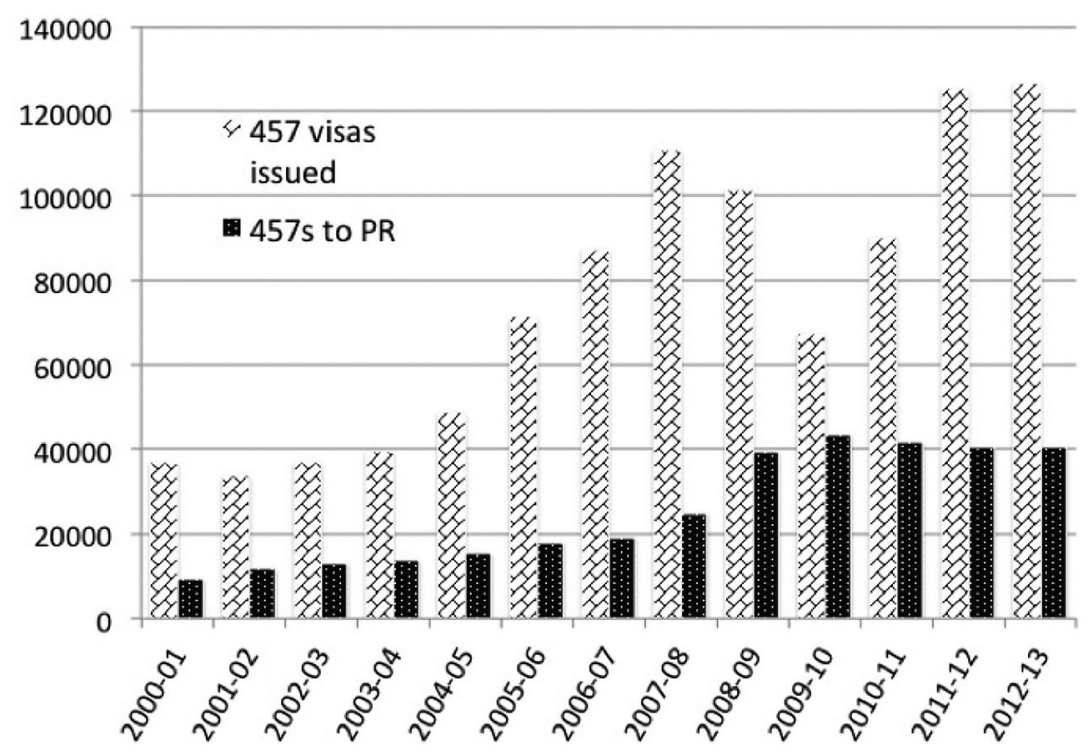

Figure 4.6: Conversion of 457 visas to permanent residency.

Source: Department of Immigration and Citizenship. ${ }^{64}$

62 Cindy Tilbrook, 'International Students: Perspectives and Graduate Outcomes' (Australian International Education Conference, 2007).

63 Beverly Jackling, 'The Lure of Permanent Residency and the Aspirations and Expectations of International Students Studying Accounting in Australia' (2007) 15 People and Place 31.

64 Department of Immigration and Citizenship, 'Annual Report' (2000-13); Department of Immigration and Citizenship, 'Subclass 457 State/Territory Summary Report' (2007-13). 
We can anticipate that this gap will grow larger as the demand for permanent places continues to outstrip the supply, especially given that 457 visa holders are only one category of temporary migrants seeking to convert to permanent residency. As Robertson noted in the previous chapter, 'longer-term migration' seems to be a 'core focus' of many of the migrants on relatively short-term working holiday (417) and post-study work (485) visas.

This is likely to generate a growing cohort of temporary migrants who continue living in Australia for extended periods of time on a series of temporary visas, either by repeatedly renewing an existing work visa (such as a 457 visa) or by switching between different visa categories (moving from student visa to 457 visa, for example).

The numbers involved are potentially large.

Of the 81,547 primary applications for a subclass 457 visa lodged in 2012-13, the majority $(42,610$ or 52 per cent) were lodged onshore - that is, they were lodged by people who were already present in Australia as temporary migrants. ${ }^{65}$

Similarly, in the 2012-13 financial year, approximately 53,000 international student graduates extended their stay in Australia by switching to a different temporary visa category with work rights - 32,000 moved onto a 485 temporary graduate work visa; 18,000 moved onto a temporary skilled 457 visa; and 3,000 moved onto a working holiday maker visa. ${ }^{66}$ This was more than three times the number of student graduates that moved onto a permanent skilled visa. ${ }^{67} \mathrm{~A}$ further 30,000 students shifted from one type of student visa to another - from vocational education to university education, for example. ${ }^{68}$

65 Department of Immigration and Border Protection, answer to question taken on notice, (AE14/217) Additional Estimates, Australian Senate, 25 February 2014.

66 Department of Immigration and Citizenship, 'Student Visa Program Quarterly Report Quarter Ending at 30 June 2013' (2013). The largest categories of visa holders applying onshore for 457 visas were existing 457 visa holders, international students and student graduates and working holiday makers. Only a small number of tourists were included.

67 Ibid.

68 Ibid. 
The number of student graduates transitioning to a 485 temporary graduate visa can be expected to grow substantially in coming years, because changes to the scheme introduced in March 2013 make it much easier for international students to remain living and working in Australia after completing their studies. ${ }^{69}$ The changes extend the visa's duration from 18 months to two years work visa if a student has studied in Australia for at least 16 months and completed either a bachelor's degree or a master's degree by course work. Students who complete a master's by research can qualify for a three-year visa, while those who complete a doctorate get four years.

Applicants do not need to be qualified for one of the jobs on the Skilled Occupation List (an official list of job categories deemed to be in short supply in the Australian economy), nor is there any requirement that they work in the professional field in which they qualified. Any graduate who is under 50 years of age and has competent English is eligible for a 485 visa as long as their first visa to study in Australia was granted on or after 5 November $2011 .^{70}$

The visa changes were driven by a desire to make Australian universities more attractive to full-fee paying overseas students. A review of Australia's international education industry declared in 2011 that 'the absence of clearly defined post-study work rights entitlement puts Australian universities at a very serious disadvantage compared to some of our major competitor countries', and concluded that an expanded work visa was essential to 'the ongoing viability of our universities in an increasingly competitive global market for students'.$^{71}$

With the introduction of the revamped 485 visa, it is now entirely conceivable that a student might arrive in Australia at the age of 16 to complete the final two years of high school, then go on to do a three-year undergraduate degree, a year of honours, and a two-year master's as an international student before working for three years

69 Migration Regulations 1994 (Cth); Migration Legislation Amendment Regulation (No 1) 2013 (Cth) sch 2. See also Peter Mares, 'We Know About the 457. What About the 485?' Inside Story, 28 March 2013. Available at: inside.org.au/we-know-about-the-457-what-about-the-485/.

70 Department of Immigration and Border Protection, Temporary Graduate Visa (subclass 485). Available at: www.immi.gov.au/Visas/Pages/485.aspx (site discontinued).

71 Michael Knight, 'Strategic Review of the Student Visa Program 2011' (Report to the Australian Government, June 2011) viii. 
on a 485 graduate visa. At the end of this period, the student will be aged 27 and will have spent 11 formative years in Australia. He or she will have invested tens if not hundreds of thousands of dollars on fees for education, and will very likely have paid a significant amount of tax, but will not necessarily be on a pathway to becoming an Australian resident and enjoying the rights and entitlements that go with permanent residency or citizenship.

\section{Ethical and practical problems}

What should be our ethical response to the rise of temporary migration and how should this inform policy?

We might argue, together with Michael Walzer, that all temporary labour migration should cease because it is morally objectionable and renders the nation equivalent to 'a family with live-in servants'. ${ }^{72}$ Walzer would argue that if we decide as a nation that we need to import more workers, then we should be willing to enlarge our political community to include them as citizens.

Given the spread of temporary migration programs, not just in Australia but globally, bolting horses and stable doors come to mind in response to this argument. It also fails to deal with the complexity of cross border movements - how would you apply it to international students who come to Australia initially for education, who may also work while they are here, and who intend to return to their home country, even though this intention may (and often does) change? ${ }^{73}$

Joo-Cheong Tham has approached the ethical challenge posed by temporary migration in a different way, by asking how we reconcile temporary migration with our conception of justice. He identifies four different responses to this question. ${ }^{74}$ The first is to argue that justice is irrelevant. The line of argument here makes reference to Australian Prime Minister John Howard's statement in response to the Tampa affair that 'we' (that is, sovereign governments) 'will decide

72 Michael Walzer, above fn 16, 52.

73 Shanthi Robertson, above fn 11, 24.

74 Joo-Cheong Tham, 'Multiculturalism and Temporary Migration: Where Does Justice Fit?' (Presentation to Australian Multicultural Commission roundtable, Melbourne, 15 March 2013). 
who comes to this country and the circumstances under which they come' ${ }^{75}$ Under this view, justice for temporary migrants is entirely at the discretion of the host government.

A second argument is that in questions of justice, citizens get priority. Under this view, the rights of temporary migrants exist, but in any conflict will always be trumped by the rights of citizens. We can see this view reflected in the comments of former Prime Minister Julia Gillard that she wanted 'to stop foreign workers being put at the front of the queue with Australian workers at the back'.$^{76}$ We might have some sympathy for this view, but question how far it should go. Does it mean, as some unions have argued for example, that in the case of redundancies, temporary migrant workers should always be sacked first? This is dangerous territory, because it grants employers arbitrary power over a particular group of workers that could result in exploitation.

As Tham says, '[i]t is one thing to design immigration admission criteria administered by government departments' to give priority to the employment of citizens and permanent residents, but another to do this 'through private sector actors'. ${ }^{77}$

The third approach identified by Tham is 'justice based on choice'. Under this view, temporary migrants have implicitly accepted the rules of the game by deciding to come to Australia in the first place. They have chosen to make their beds in Australia, and they should lie in them, without complaint.

But this 'take it or leave it' approach runs contrary to our understanding of Australia as a nation based on liberal democratic values, 'principles that organise - and encourage - engagement, debate and disagreement in the political process' ${ }^{78}$ This approach also ignores the impact of time, and the way in which duration of stay not only gives rise to a sense of belonging on the side of the migrant, but also to ethical obligations on the part of the recipient state. As Carens argues:

75 John Howard, Speech at the Federal Liberal Party Campaign Launch (28 October 2001).

76 The Economist, 'Winning the West', 16 March 2013. Available at: www.economist.com/ news/asia/21573609-prime-minister-canvasses-fast-changing-suburbs-winning-west.

77 Joo-Cheong Tham, above fn 74.

78 Ibid. 
The ties that come from actually living in a state are the most powerful basis for a claim to membership. Home is where one lives, and where one lives is the crucial variable for interests and for identity, both empirically and normatively. ${ }^{79}$

Tham's fourth - and preferred - approach to the question of justice for temporary migrants is justice as fairness. This does not mean identical treatment for everyone — whether citizen, permanent resident, or temporary migrant — but it does mean bringing the concept of fairness into play when considering the rights and entitlements of long-term temporary migrants who are making a significant contribution to the economic, social, and cultural life of the nation.

Introducing notions of fairness into the discussion does not automatically solve practical policy questions, but it does at least change the nature of the debate because it forces us to conceptualise long-term temporary migrants as human beings, rather than as "pure" economic inputs' who can be expected to simply depart when their labour is no longer required or their tuition fees have been expended. ${ }^{80}$

Applying the lens of fairness can help us to respond to the case studies outlined above, although it does not obviate the need to make normative judgements that will be open to contestation. As Carens notes, 'the extremes will be clear, the middle will be fuzzy' ${ }^{81}$

Let us begin with the case of Claire Hewitt. The premise of fairness would require that a temporary migrant worker be entitled to the same workplace rights and entitlement as an employee who is an Australian citizen or permanent resident. This is the conclusion reached by Carens, who argues that 'minimum acceptable working conditions' are based on 'the understanding of what is acceptable that is generated by the community's internal democratic processes' ${ }^{82}$ On this basis, the state should regulate working conditions in the same way for citizens, residents, and temporary migrants. ${ }^{83}$

\footnotetext{
79 Joseph Carens, The Ethics of Immigration (Oxford University Press, 2013) 31.

80 Catherine Dauvergne and Sarah Marsden, above fn 6.

81 Joseph H Carens, above fn 8, 435.

82 Ibid., 426.

83 One potential exception to this principle is labour mobility - that is, whether a temporary migrant is tied to a particular employer or is at liberty to change jobs. This issue is discussed further below, in the context of economic and social rights.
} 
Indeed, this appears to be the foundation of present policy in Australia, which requires potential employers to show that they will provide 'no less favourable terms and conditions of employment' to a 457 visa holder 'than they would to an equivalent Australian in the sponsor's workplace at the same location' ${ }^{84}$ Further, 457 visa holders are entitled to the same 'basic rights and protections in the workplace' 85 as Australian employees, including the right not to be dismissed unfairly' and 'the right to join and be represented by a trade union' ${ }^{86}$

If we apply this logic to the case of Claire Hewitt, then the fair course of action becomes apparent. Given that her accident was a workplace accident, she should be treated no differently to a citizen or permanent resident in the same situation. The intent of the Workers Rehabilitation and Compensation Act (NT) should be honoured. If giving full effect to the meaning of rehabilitation under the Act requires that Claire Hewitt be granted permanent residency, then that is what should happen (and the legislation of this and other comparable Acts around Australia should be amended accordingly to ensure that temporary migrant workers affected by workplace accidents are treated on equal terms with their Australian colleagues). ${ }^{87}$

If we apply the same principles of fairness and equality in workplace rights and entitlements to the second case study of international students formerly employed by the collapsed Swan Services Cleaning Group, then we will reach a similar conclusion. The eligibility definitions in the Fair Entitlements Guarantee Act 2012 (Cth) should be amended to extend coverage to temporary migrants with work rights, such as international students and 457 visa holders.

The issues involved in case studies three and four are potentially more complex, since they raise questions about access to government services. These are rights and entitlements that do not emanate from an employment relationship in the workplace but from physical

\footnotetext{
84 Department of Immigration and Border Protection, 'Temporary Work (Skilled) (subclass 457) Visa Information Booklet'. Available at: www.immi.gov.au/allforms/booklets/books9.pdf (site discontinued).

85 Ibid., 47.

86 Ibid., 48.

87 An alternative way of looking at Hewitt's case would be to regard workplace injury compensation as a contributory insurance scheme, albeit with the employer, rather than the employee, paying the premiums. But even if we take this approach, the 'fair' outcome would be the same, for reasons discussed below.
} 
presence within the boundaries of a political community. Questions of fairness thus run in two directions: is it fair that citizens and permanent residents should contribute via taxation to the welfare of migrants whose stay in Australia may only be temporary and whose contribution to government revenue may be limited as a result?

This returns us to the puzzling problem identified by Carens:

What are the claims of non-citizens who are present on the territory of a state but who are not permanent residents? Does the normative map of democracy have room for them ${ }^{88}$

Taken narrowly, the issues of access to emergency disaster relief, disability care, and childhood immunisation can be seen as questions of entitlement to government-funded services and welfare. As we shall see, however, digging around in such particular issues soon raises the broader question of political belonging and whether, as Carens argues, the passage of time means that a 'temporary visa ... ought at some point to be converted into a right of permanent residence' ${ }^{89}$

Let us restrict our gaze for now to the question of government services.

In this context, Martin Ruhs distinguishes between 'contributory' and 'means-tested' entitlements. ${ }^{90}$ Carens makes a similar distinction between 'social programs directly tied to workforce participation' (such as unemployment insurance and compulsory retirement savings schemes) and 'other social programs', which might include healthcare, education, low income tax credits, 'and anything else the state spends money on for the benefit of the domestic population' ${ }^{91}$

If we follow Carens and Ruhs, temporary migrants should be entitled to benefits under the former category, but not necessarily under the latter. In an Australian context, compulsory superannuation payments would be an example of a 'contributory' entitlement and it is uncontroversial that migrant workers retain ownership of their accumulated funds.

\footnotetext{
88 Joseph H Carens, above fn 8, 420.

89 Ibid., 422.

90 Martin Ruhs, The Price of Rights: Regulating International Labour Migration (Princeton University Press, 2013) 189.

91 Joseph H Carens, above fn 8, 425.
} 
Most government services in Australia are funded through general taxation revenue, however, and would fall into the latter category, although the situation is not straightforward. Healthcare and school education in Australia are universal and not means-tested. They are not 'contributory' or 'directly tied to workplace participation' as such, but in the case of Medicare, the costs are partly recovered through a specific levy on income. This is also true of the National Disability Insurance Scheme.

Most government-funded or subsidised services are automatically available regardless of an individual's visa status. You do not need to prove residency to use public transport or call on the help of police or the fire brigade. Carens argues that fundamental entitlements like healthcare and school education should also be treated in this manner:

... any state that treats health care as a basic right ... is obliged to provide health care to temporary workers, and their families, too, if they are present. Every democratic state has a system of free and compulsory public education, and again, temporary workers have a right to this education for their children if their children are present. ${ }^{92}$

Carens also argues that:

It is blatantly unfair to require people to pay into an insurance scheme if they are not eligible for the benefits. This violates an elementary principle of reciprocity. ${ }^{93}$

Applying Carens' logic would require New Zealanders on SCVs to be included in the National Disability Insurance Scheme, potentially after some qualification period linked to the duration of their residency. It would also require that the children of long-term temporary migrants be provided with free immunisation, and would also entitle those children to free education (which 457 visa holders are entitled to in some states but not in others).

Carens also provides the basis for arguing for a change of policy such that all long-term temporary migrants would be eligible for services under Medicare and the National Disability Insurance Scheme, if they

92 Ibid., 429.

93 Ibid., 426. 
pay the appropriate levies, and again, after an appropriate qualification period linked to the amount of time they have spent living, working, and paying tax in Australia.

But what might an appropriate qualification period be? This is also the question that confronts us in relation to disaster relief and after what period long-term temporary migrants, such as New Zealander SCV holders, should be entitled to emergency payments during events such as floods and bushfires. In other words, it brings us back to the Carens core question of political belonging.

As Dauvergne and Marsden point out, expanding the 'rights' of temporary migrants can bring them tangible benefits, but can only go so far before running up against its inherent limitation:

It is impossible ... within rights discourse, to erase the underlying subordination of temporary migrant workers. Talking in rights terms, inevitably calls up the 'right' of the state to exclude non-members as an aspect of sovereignty. This exclusion power undermines attempts to articulate rights claims for those with any type of temporary status, and reinforces a fundamental inequality between citizens and noncitizens. ${ }^{94}$

Ruhs identifies the same problem in a different way, when he argues that there should be no restrictions on the fundamental civil and political rights of temporary migrant workers - such as freedom of thought and expression, freedom of religious belief and worship, and freedom of association - with the crucial exception of the right to vote in national elections and the right to run for public office. ${ }^{95}$ These are two rights that usually demarcate the boundaries of citizenship.

As long as migrants remain temporary, they remain outside that boundary. And while Ruhs accepts restrictions on certain social and economic rights of temporary migrants - not just government benefits but also the right to family reunion and freedom of movement within the labour market - his caveat is that any such restrictions

94 Catherine Dauvergne and Sarah Marsden, above fn 6, 237.

95 Martin Ruhs, above fn 91, 187. 
must be time limited. He argues, following Carens, that 'the passage of time' is 'the most important consideration' in strengthening migrants' 'moral claims'.${ }^{96}$

Ruhs thus concludes that there should be a point at which temporary migrants are either granted permanent residence or required to return home. He rejects potential outcomes in which migrants repeatedly renew time-limited visas or cycle through different categories of temporary visas, as can potentially happen in Australia today. If restrictions on migrants' social and economic rights are not timelimited, he argues, then we risk creating a group of 'second-class residents' - residents who are not only at risk of being permanently temporary, but are also at risk of being permanently excluded from the political community of the nation, and permanently denied the benefits and rights of citizenship. ${ }^{97}$

What should this time limit be? Ruhs considers four years equivalent to a single term on a 457 visa - to be a reasonable period, though he offers little justification for choosing this number beyond gut feeling - less than three years seems too short and more than five years seems too long. ${ }^{98}$

In her review of the integrity of the 457 visa system, Industrial Relations Commissioner Barbara Deegan reached a similar conclusion to Ruhs on the indefinite and repeated renewal of temporary work permits, recommending that no 457 visa holder 'be permitted to remain in Australia for more than 8 years in total'.$^{99}$ If they were unable to convert to permanent residency after that time, she recommended that they be required to leave Australia.

In Australia, we have established other time thresholds in relation to migration. For example, a permanent resident must wait two years to become eligible for most social security payments, ${ }^{100}$ and a permanent resident must satisfy a four-year residency requirement

\footnotetext{
96 Joseph H Carens, Immigrants and the Right to Stay (MIT Press, 2010) 6. (Carens was referring here to irregular migrants but the same principle is applicable to temporary migrants.)

97 Martin Ruhs, above fn 91, 191.

98 Ibid., 192.

99 Barbara Deegan, above fn 2.

100 Department of Human Services, Australian Government, Newly Arrived Resident's Waiting Period. Available at: www.humanservices.gov.au/customer/enablers/newly-arrived-residentswaiting-period.
} 
before applying for citizenship. ${ }^{101}$ There is a 10-year time frame after which a child born in Australia to non-citizen or non-resident parents gains the right to citizenship. ${ }^{102}$ Another 10-year time frame applies to limited access to certain government benefits for New Zealanders on non-protected SCVs. ${ }^{103}$

There is a proposal to introduce a similar 10-year residency threshold to enable New Zealand SCV holders who arrived in Australia as children to gain access to the Higher Education Contribution Scheme/ Higher Education Loan Programme loans scheme to attend university or TAFE. ${ }^{104}$ (Currently they must pay upfront fees.)

If we were to apply Ruhs' approach of gut feeling to this issue, then 10 years would appear a very long qualification period. By comparison, Carens notes a European Union directive that recommends that 'third country nationals (that is, people from outside the EU) be granted a right of permanent residence if they have been legally residing in a single EU state for five years'. ${ }^{105}$ Time spent in the country as a student is discounted by 50 per cent as long as the applicant has held another temporary resident status in addition to student status. ${ }^{106}$ In Canada, a temporary migration scheme for live-in caregivers leads to permanent residency after two years full-time employment. ${ }^{107}$

The point of such examples is not to suggest that there is an objectively identifiable or average time period at which temporary migration should transition to permanent residence (or before which long-

101 Australian Citizenship Act 2007 (Cth) pt 2 div 1 s 22.

102 Ibid., pt 2 div 1 s 12 (b).

103 If you arrived in Australia on a New Zealand passport and have lived here for at least 10 continuous years since 26 February 2001, you may be able to access a once-only payment of Newstart Allowance, Sickness Allowance, or Youth Allowance. If you are eligible, payment can be made for a maximum continuous period of up to six months. See Department of Human Services, Australian Government, New Zealand Citizens Claiming Payments in Australia. Available at: www.humanservices.gov.au/customer/enablers/nz-citizens-claiming-payments-inaustralia.

104 Radio New Zealand News, Some Kiwi Students to Get Australian Loans. Available at: www. radionz.co.nz/news/political/235456/some-kiwi-students-to-get-australian-loans.

105 Joseph H Carens, above fn 8, 419. The directive in question is European Council Directive 2003/109/EC.

106 Shanthi Robertson, above fn 11, 38. This means, for example, that a combination of four years study and three years work would render a temporary migrant eligible.

107 Citizenship and Immigration Canada, Become a Permanent Resident: Live-in Caregivers (19 October 2012). Available at: www.cic.gc.ca/english/work/caregiver/permanent_resident.asp. 
term temporary migration should be curtailed and migrants forced to leave). Rather, it is to agree with Carens that 'some threshold must be established beyond which the right to stay is indefeasible'. ${ }^{108}$

As with the time thresholds described above, there will, inevitably, be an element of arbitrariness as to where the limit is set:

Why five years rather than four or six? No one can pretend that the answer to this question entails any fundamental principle. It is more a matter of the social psychology of coordination, given the need to settle on one point within a range. But if one asks why five years rather than one or ten, it is easier to make the case that one is too short and ten too long, given common European understandings of the ways in which people settle into the societies where they live. ${ }^{109}$

Accepting the need for some limit presupposes accepting Carens' argument that 'the longer one stays in a society, the stronger one's claim to remain'. ${ }^{110}$ But this appears to be a widely accepted common sense understanding. As former immigration minister Scott Morrison acknowledged (whilst still in Opposition):

When we arrive in this country, we become part of it - and it becomes a part of us - it becomes what [Sir Henry] Parkes described as 'the land of our adoption'. It changes us - and in doing so it provides the basis for our connection with one another. ${ }^{111}$

Migrants who live in Australia for a significant period of time, who contribute to the economic life of the nation through their labour and their taxes, and who possibly pay fees to study, are people who, for all intents and purposes, make Australia their home.

Should we, as Ruhs and Deegan suggest, force people to leave before that connection becomes too strong - that is, before their emotional, psychological, financial, and cultural bonds to Australia reach the point at which 'a threshold is crossed, and they acquire a moral claim to have their actual social membership legally recognised'? ${ }^{112}$ If so, should the time limit be four years, or five, or six, or 10? Is it also

\footnotetext{
108 Joseph H Carens, above fn 8, 422.

109 Ibid.

110 Ibid.

111 Scott Morrison, 'Reasons to Be Optimistic about Australia's Immigration Future' (Address to the Affinity Intercultural Foundation, Sydney, 17 July 2013).

112 Joseph H Carens, Immigrants and the Right to Stay, above fn 97, 18.
} 
plausible that the moral claim that increases with duration of stay might be linked to the age and life stage of the person in question? Does it make a difference, for example, if a 24-year-old has spent eight years - a third of his or her life - living in Australia since the age of 16, compared to a 48-year-old who arrived at age 40 and who has spent only one-sixth of his or her life here? Should a point come at which continuous residency automatically confers the right of permanency? Such an option may have its own unintended consequences. ${ }^{113}$ Is there a middle way, in which each year of temporary residence increases an applicant's points in an application for permanent residency, perhaps with time spent as a student discounted as compared to time spent as an employee?

As Australia's system of temporary migration continues to expand, it moves us further away from the postwar certainties of settler migration. Yet, as Robertson notes, 'countries like Australia are, conceptually and politically, largely unprepared for the consequences of increased temporary migration schemes', ${ }^{114}$ (intended and unintended). We talk about temporary migration quite a lot in Australia, but debate still tends to be limited to the specifics of rights and entitlements. For example, we question whether international students qualify for public transport discounts, or whether 457 visa holders should pay for their children to attend state schools. Similarly, we debate issues of enforcement and protection - how do we ensure that temporary migrant workers are not exploited at work? These are legitimate and important matters, but as I have argued above, they lead ultimately to the larger threshold question of political membership: at what point does, or should, 'temporary' become 'permanent'? There is no simple answer to this question, and any answer will be contested. It is a matter that can only be resolved politically, and a political response can only be generated through robust debate. Currently, however, we generally fail to pose the question at all.

113 For example, there have been cases in which undocumented migrants have sought to extend their stay in Australia in order for an Australian-born child to cross the 10-year threshold required for citizenship. See Peter Mares, 'A Routine Removal' (2007) 18 Griffith Review 205.

114 Shanthi Robertson, above fn 11, 167. 


\section{Bibliography}

\section{Articles, books, and reports}

Carens, Joseph H, 'Live-in Domestics, Seasonal Workers, and Others Hard to Locate on the Map of Democracy' (2008) 16 The Journal of Political Philosophy 419

Carens, Joseph H, Immigrants and the Right to Stay (MIT Press, 2010)

Carens, Joseph H, The Ethics of Immigration (Oxford University Press, 2013)

Dauvergne, Barbara and Sarah Marsden, 'The Ideology of Temporary Labour Migration in the Post-Global Era' (2014) 18 Citizenship Studies 224

Deegan, Barbara, 'Visa Subclass 457 Integrity Review: Final Report' (2008). Available at: www.border.gov.au/WorkinginAustralia/ Documents/457-integrity-review.pdf

Department of Immigration and Citizenship, 'Annual Report' (2000-13)

Department of Immigration and Citizenship, 'Working Holiday and Work and Holiday Visa Report 2005-06 to 2009-10 Program Years' (2005-10)

Department of Immigration and Citizenship, 'Subclass 457 State/ Territory Summary Report' (2007-13)

Department of Immigration and Citizenship, 'Australian Migration Trends 2011-12' (2012)

Department of Immigration and Citizenship, 'Student Visa Program Quarterly Report Quarter Ending at 30 June 2013' (2013)

Department of Immigration and Citizenship, 'Working Holiday Maker Visa Program Report Ending at 30 June 2013' (2013)

Faulkner, David, 'The Unequal Treatment of New Zealanders in Australia' (2013). Available at: papers.ssrn.com/sol3/papers. cfm?abstract_id $=2304476$ 
Jackling, Beverly, 'The Lure of Permanent Residency and the Aspirations and Expectations of International Students Studying Accounting in Australia' (2007) 15 People and Place 31

Khoo, Siew-Ean, Graeme Hugo and Peter McDonald, 'Which Skilled Temporary Migrants Become Permanent Residents and Why?' (2008) 42 International Migration Review 193

Knight, Michael, 'Strategic Review of the Student Visa Program 2011' (Report to the Australian Government, June 2011)

Mares, Peter, 'A Routine Removal' (2007) 18 Griffith Review 205

Mares, Peter, 'A Special Category' (2014) 43 Griffith Review. Available at: griffithreview.com/articles/9677/

Migration Council Australia, 'More Than Temporary: Australia's 457 Visa Program' (2013)

National Centre for Immunisation Research and Surveillance, 'Biennial Report: January 2010-November 2011' (2012). Available at: www.ncirs.edu.au/assets/publications/reports/NCIRS-biennialreport-2010-2011.pdf

Robertson, Shanthi, Transnational Student-Migrants and the State: The Education-Migration Nexus (Palgrave Macmillan, 2013)

Ruhs, Martin, The Price of Rights: Regulating International Labour Migration (Princeton University Press, 2013)

Tilbrook, Cindy, 'International Students: Perspectives and Graduate Outcomes' (Australian International Education Conference, 2007)

Walzer, Michael, Spheres of Justice: A Defense of Pluralism and Equality (Basic Books, 1983)

\section{Legislation}

Australian Citizenship Act 2007 (Cth)

Fair Entitlements Guarantee Act 2012 (Cth)

Family And Community Services Legislation Amendment

(New Zealand Citizens) Bill 2001 
UNINTENDED CONSEQUENCES

Health Insurance Act 1973 (Cth)

Migration Act 1958 (Cth)

Migration Legislation Amendment Regulation (No 1) 2013 (Cth)

Migration Regulations 1994 (Cth)

National Disability Insurance Scheme Act 2013 (Cth)

Workers Rehabilitation and Compensation Act 2014 (NT)

\section{Other}

Australian Bureau of Statistics, Series 6202: Labour Force, Australia. Available at: www.abs.gov.au/ausstats/abs\%40.nsf/mf/6202.0

Citizenship and Immigration Canada, Become a Permanent Resident: Live-in Caregivers (19 October 2012). Available at: www.cic.gc.ca/ english/work/caregiver/permanent_resident.asp

Commonwealth of Australia, Additional Estimates (AE14/217) Programe 1.1 Visa and Migration (25 February 2014)

Department of Health, Victorian Government, Free Vaccine VictoriaCriteria For Eligibility. Available at: www.health.vic.gov.au/ immunisation/free-vaccine.htm (site discontinued)

Department of Human Services, Australian Government, Ex-Gratia Assistance For New Zealand Non-Protected Special Category Visa Holders: New South Wales Floods January 2013. Available at: www. humanservices.gov.au/spw/customer/forms/resources/em039130215en.pdf (site discontinued)

Department of Human Services, Australian Government, Ex-Gratia Assistance for New Zealand Non-Protected Special Category Visa Holders: Queensland Floods January 2013. Available at: www. humanservices.gov.au/spw/customer/forms/resources/em037130212en.pdf (site discontinued)

Department of Human Services, Australian Government, Ex-Gratia Income Support Allowance for New Zealand Non-Protected Special Category Visa Holders: NSW Bushfires October 2013. Available at: 
www.humanservices.gov.au/customer/enablers/centrelink/disasterrecovery-allowance/ex-gratia-income-support-allowance-nswbushfires-oct-2013\#a4 (site discontinued)

Department of Human Services, Australian Government, New South Wales Bushfires: October 2013. Available at: www.human services.gov.au/customer/services/centrelink/dra-nsw-bushfiresoctober-2013

Department of Human Services, Australian Government, New Zealand Citizens Claiming Payments in Australia. Available at: www. humanservices.gov.au/customer/enablers/nz-citizens-claimingpayments-in-australia

Department of Human Services, Australian Government, Newly Arrived Resident's Waiting Period. Available at: www.humanservices.gov. au/customer/enablers/newly-arrived-residents-waiting-period

Department of Human Services, Australian Government, Western Australia Bushfires: January 2014. Available at: www. humanservices.gov.au/customer/enablers/centrelink/australiangovernment-disaster-recovery-payment/western-australiabushfires-january-2014 (site discontinued)

Department of Immigration and Border Protection, Temporary Graduate Visa (subclass 485). Available at: www.immi.gov.au/ Visas/Pages/485.aspx (site discontinued)

Department of Immigration and Border Protection, Temporary Work (Skilled) (subclass 457) Visa Information Booklet. Available at: www.immi.gov.au/allforms/booklets/books9.pdf (site discontinued)

Department of Immigration and Citizenship, Temporary Entrants and NZ Citizens in Australia, Quarterly Reports (2011-13)

Department of Immigration and Border Protection, Ministerial Intervention (14 May 2014). Available at: www.immi.gov.au/ refugee/ministerial_intervention.htm

Donnell, Hayden, 'New Zealand Pair Upset at Flood Cash "Racism"', New Zealand Herald, 21 January 2011 . Available at: www.nzherald. co.nz/nz/news/article.cfm?c_id $=1 \&$ objectid $=10701102$ 
The Economist, 'Winning the West', 16 March 2013. Available at: www. economist.com/news/asia/21573609-prime-minister-canvassesfast-changing-suburbs-winning-west

Email from Les Koopowitz to the author (23 October 2013)

Heather, Ben, 'Kiwis' Australian Care Case Settled', Stuff NZ, 25 October 2012. Available at: www.stuff.co.nz/world/australia/7858803/ Kiwis-Australian-care-case-settled

Heffernan, Madeleine and Clay Lucas, 'International Students Taken to the Cleaners', The Age, 2 June 2013. Available at: www.theage. com.au/national/international-students-taken-to-the-cleaners20130601-2nily.html\#ixzz2iQHeVVzW

Howard, John, Speech at the Federal Liberal Party Campaign Launch (28 October 2001)

Interview with Claire Hewitt (29 August 2013)

Mares, Peter, 'Lives On Hold', Inside Story, 2 May 2011. Available at: inside.org.au/lives-on-hold/

Mares, Peter, 'Temporary Migration is a Permanent Thing', Inside Story, 20 March 2013. Available at: inside.org.au/temporarymigration-is-a-permanent-thing/

Mares, Peter, 'We Know About the 457. What About the 485?' Inside Story, 28 March 2013. Available at: inside.org.au/we-know-aboutthe-457-what-about-the-485/

Mares, Peter, 'Falling Between the Cracks of Temporary Migration', Inside Story, 1 November 2013. Available at: inside.org.au/fallingbetween-the-cracks-of-temporary-migration/

McMillan, Kate and Paul Harmer, 'Kiwis in Australia Deserve Better', New Zealand Herald, 10 October 2013. Available at: www.nzherald. co.nz/nz/news/article.cfm?c_id=1\&objectid=11137557

Melbourne School of Population and Global Health, Indigenous Eye Health Unit, The Trachoma Story Kit. Available at: iehu.unimelb. edu.au/the_trachoma_story_kit/introduction 
Morrison, Scott, 'Our Nation' (Address to the 2011 Federation of Ethnic Community Councils of Australia Conference, Adelaide, 18 November 2011). Available at: australianpolitics. com/2011/11/18/morrison-promises-to-protect-the-borders-of-ourvalues.html\#more-4574

Morrison, Scott, 'Doing Far More to Build Our Nation' (Address to the Affinity Intercultural Foundation, Sydney, 17 July 2013). Available at: www.affinity.org.au/wp-content/uploads/2013/07/MorrisonDoing-far-more-to-build-our-nation-170713.pdf

Morrison, Scott, 'Reasons to Be Optimistic about Australia's Immigration Future' (Speech at the Affinity Intercultural Foundation, Sydney, 17 July 2013)

The National Health Performance Authority, Healthy Communities: Immunization Rates for Children in 2012-13. Available at: www. myhealthycommunities.gov.au/Content/publications/downloads/ NHPA_HC_Report_Imm_Rates_March_2014.pdf

The National Health Performance Authority, 'Childhood Immunisation Rates Up, But Some Areas Still Low’, (Media Release, 24 March 2014)

New Zealand High Commission Canberra, Australia, Floods Assistance. Available at: www.nzembassy.com/australia/news/queenslandfloods-assistance (site discontinued)

NHMRC Centre for Research Excellence in Population Health, Protecting Australia: Closing the Gap in Immunisation for Migrants and Refugees: Proceedings from a Stakeholder Workshop. Available at: www.creimmunisation.com.au/sites/ default/files/newsevents/events/CREMigrantRefugeeWorkshop_ ProceedingsRecommendations.pdf

Radio New Zealand News, Some Kiwi Students to Get Australian Loans. Available at: www.radionz.co.nz/news/political/235456/somekiwi-students-to-get-australian-loans

Tham, Joo-Cheong,'Multiculturalism and Temporary Migration: Where Does Justice Fit?' (Presentation to Australian Multicultural Commission roundtable, Melbourne, 15 March 2013)

United Voice, Swan Cleaning Services Update (5 June 2013). Available at: www.unitedvoice.org.au/news/swan-cleaning-services-update 
This text is taken from Unintended Consequences: The impact of migration law and policy, edited by Marianne Dickie, Dorota Gozdecka and Sudrishti Reich, published 2016 by ANU Press, The Australian National University, Canberra, Australia.

The papers published in this book arose from an inaugural conference on migration law and policy at ANU College of Law, held in October 2013. They are reprinted here with minor amendments. 